денческая постановочная работа будет наполнена новым содержанием и более вдумчивым поиском новых выразительных средств одного из направлений современного танца «фолк».

\section{Список литературы}

1. Устяхин С. В. Тенденции развития фолктанца как направления современной хореографии: дисс. ... канд. культурологии. Саранск, 2006. $190 \mathrm{c}$.

2. Полякова А. С. «Танец постфолк»: к исследованию одного из феноменов современного танца // Обсерватория культуры. 2017. № 14 (4). C. 425-430.

3. URL: https://doi.org/10.25281/2072-31562017-14-4-425-430 (23.03.2021).
4. Васенина Е. В. Современный танец постсоветского пространства. Москва, 2013. 322 с.

5. Полякова А. С. «Танец постфолк»: к исследованию одного из феноменов современного танца. Обсерватория культуры. 2017. № 14 (4). C. 425-430. URL: https://doi.org/10.25281/20723156-2017-14-4-425-430_(20.03.2021).

6. Хабибуллина Л. «Надо проживать каждую секунду» Петербергский театральный журнал № 2 (32) 2003 URL: http://ptj.spb.ru/archive/ 32/music-theatre-32/nado-prozhivat-kazhduyusekundu/ (20.03.2021).

7. Духина И. «Энергия невесомости. Театр современного танца обживает новый дом». 9 ноября 2019. Газета «Южноуральская панорама», https://up74.ru/articles/kultura/115469/ (20.03.2021).

\title{
ПЕДАГОГИЧЕСКИЙ ПОТЕНЦИАЛ «ДОКУМЕНТАЛЬНОГО ТЕАТРА» В СОВРЕМЕННОЙ ТЕАТРАЛЬНОЙ ШКОЛЕ
}

\begin{abstract}
Аннотация. Данная статья посвящена исследованию одной из образовательных технологий современной театральной школы - «методу документального театра». Обобщив практический опыт, автор приходит к следующим выводам: документальный театр позволяет быстрее находить острые социальные проблемы, помогает личностно погрузиться в изучение повседневности и человека, начать осознанно анализировать существующие проблемы, тем самым способствует формированию активной гражданской позиции будущих актёров и режиссёров.
\end{abstract}

Ключевые слова: театральная школа, сиеническая педагогика, документальный театр, актёрское мастерство, художественный метод, гражданская позиция.

Основным и бесспорным постулатом всякой театральной школы является формирование и раскрытие гармоничной творческой личности ученика. Л. В. Грачева в статье «Есть такая профессия - театральный педагог» пишет о специфике театрального педагога так: «Сценическую педагогику отличает от прочих чрезвычайно тонкий объект - не ученик, не “педагогический факт" - а душа художника. Сценическая педагогика занимается “воспитанием чувств" в самом прямом, а не литературном значении этих слов» $[1$, с. 7$]$.

И действительно, театральная школа должна заниматься не только профессиональным воспитанием, но ещё эстетическим и этическим воспитанием. К этому необходимо серьезное отношение, ведь театральная школа должна способствовать формированию мировоззрения, гражданской позиции, художественного вкуса и морального облика.

Г. А. Товстоногов писал, что «водораздел между подлинным искусством и ремеслом лежит именно в плоскости идейно-нравственных начал: есть ли у режиссера чувство гражданской ответственности или оно отсутствует» [2, с. 56]. Идейная и гражданская направленность художника, его верное мировоззрение - первооснова искусства. Мировоззрение режиссера и его общественный темперамент порождает эмоциональное зерно спектакля.

Студенты театрального отделения с самого начала обучения должны осознавать свою ответственность перед гражданским обществом. Г. А. Товстоногов в беседе со студентами первого курса делал особый акцент на гражданственность театрального искусства. Он говорил: 
«Компас режиссера - это его гражданская позиция. Позиция активная, страстная. Продуманная и прочувствованная сердцем. Сердцем большим, открытым людям. Все в нашем искусстве бессмысленно и никчемно, если не освящено большим гражданским чувством» [2, с. 62].

В наши дни проблема воспитания гражданских чувств у студентов творческого направления является актуальной.

Театровед и культуролог Полина Богданова в своей книге «Культурный цикл: театральная режиссура от шестидесятников к поколению post» определяет причинно-следственные связи, способствующие потере идентичности России. «Перестройка», ставшая шоковым для нашей страны событием конца XX века, породила нестабильность во всех сферах, привела к краху нравственных и общекультурных постулатов, который наиболее остро ощущается на сегодняшний день [4, с. 187-188].

Стремительному и болезненному процессу краха прежней системы ценностей способствовали переход государственной собственности в частные руки и ослабление роли государства со всеми его институтами. И, в результате, человек оказался представленным самому себе, он больше не мог рассчитывать на опеку государства. Начавшееся активное «процветание» криминальных структур, которые стали заполнять социальное пространство, усугубило общую дисгармонию общества. Всё это привело к изменению нравственного климата в обществе.

Американский социолог Д. Сибрук утверждает, что в «эпоху перестройки» возникает новый тип культуры, который он определяет, как «культуру супермаркета» [3, с. 24]. В эпоху «перестройки» стали появляться гигантские супермаркеты, в которые большим потоком хлынули импортные продукты питания и товары. Отправной точкой в развитии общества потребления в постсоветской жизни становится шопинг. Соответственно, театр, как и другие виды искусства, в таком обществе так же превращаются в товар. И в театре на первое место уже выходит не художественное качество, а занимательность спектакля, где нет перегруженности смыслом, а превалирует эффектное зрелище.

У поколений, рождённых в постсоветское время, сформировалось негативное настроение по отношению к советской идеологии, породившее яростное желание сбросить его, и не предложивших, как показали дальнейшие события, ничего принципиально нового. Основным стремлением современного поколения является не развитие, а смена русской идентичности. Это обосновано ориентацией современного поколения на западную модель жизни, которое выражено в стремлении к комфорту, в формировании идеологии либерализма, утилитаризма и пользы.

В постсоветское время общество отказывается от той самой интеллигенции, которая в советское время, будучи передовой частью общества, являлась своего рода «законодательницей» в сфере нравственных, моральных и творческих критериев. Соответственно, статус творческих профессий вместе со статусом культуры и искусства понизился.

Автор исследования солидарен с мнением известного театроведа и культуролога Полины Богдановой, что в эпоху постмодерна художник больше не мог претендовать на роль общественного лидера и идеолога в жизни [4, с. 193].

Суть стратегии режиссуры в эпоху модерна в том, что режиссёр выступал как общественный художественный лидер, направляющий общественное сознание. Художник-модернист требует от публики определённо высокого уровня мышления и вкуса. Художникумодернисту свойственно «завышенное самосознание», «ощущение призванности». Художник в эпоху постмодернизма испытывает острый «кризис профессионализма», ему присуща точка зрения обывателя, дилетанта и графомана.

Кризис современного театрального образования ощущается в нехватке современных художественных методов и приёмов в воспитание гармоничной личности, художника, творца, с активной гражданской позицией и жизнеутверждающим мировоззрением.

Гражданская активность, по мнению Г. А. Товстоногова выражается в умении воспринять «стремления народа, его беды, радости как свои личные» $[2$, с. 76]. А режиссер обнаруживает свою гражданскую убежденность в своем искусстве.

Одной из тенденций современного театрального образования является активное использование метода документального театра в обучении будущих актёров и режиссёров. Этот факт подтверждается возросшим количеством за последние несколько лет студенческих документальных спектаклей ведущих театральных вузов России, которые имеют культурный резонанс и занимают, по мнению авторитетных театральных деятелей, верхние строчки театрального рейтинга.

История развития документального театра в России началась в 1920-е годы, когда страна переживала сильные социальные потрясения, 
и нуждалась в новом искусстве. Появление агитационного театрального коллектива «Синяя блуза» помогало малограмотному населению доступно узнать о происходящих событиях. «Синяя блуза» театральными средствами выразительности, с песнями и танцами инсценировали актуальные новости. После успеха выступлений агитационного коллектива «Синяя блуза» такие же «живые газеты» активно стали появляться не только в других городах, но и на многих европейских площадках.

В книге «Беседы с коллегами» именитый режиссёр Георгий Товстоногов даёт высокую оценку театральной документалистики: «Мне вообще непонятно утверждение, что производственные пьесы - не предмет театра, а публицистика. Публицистика - тоже искусство. <..> Вы слышали, как зал принимал «Протокол одного заседания» [пьесу Александра Гельмана]? Как же можно игнорировать то обстоятельство, что люди выходят из зала взволнованные? Они живут этими проблемами, и, когда слышат со сцены честный разговор на затрагивающие их темы, театр становится им интересным. Нельзя проходить мимо этого. И если вы лично не приемлете такую драматургию, значит, вы не живете проблемами, которые волнуют миллионы людей. Мы не можем предъявлять производственной драматургии претензии с позиции эстетики Чехова или Достоевского, надо судить ее по ее законам, а эти законы публицистические» $[5$, c. 134$]$.

В современном мире повышенный интерес к документу оправдан элементарным и открытым доступом к информации. Ценность документа продиктована еще и недостатком подлинности. Нас окружают фейки, симулякры, имитации. Документальный театр - это еще и поиск подлинности приема в обуржуазившемся, конвенциональном искусстве.

Ведущий театральных критик Павел Руднев делит документальный театр на три вида:

- театр документа, в котором предметом сценического изучения становится документ, уже существующий в реальности, как правило, документ исторического содержания;

- verbatim (вербатим), технология интервью, материалы которого становятся пособиями для копирования актерами-интервьюерами не только речи героев, но и их поведенческих стереотипов, артикуляции, манер речи, жестикуляции и т. п.;

- свидетельский театр, форма документального театра, где «документом» оказывается сам человек. В свидетельском театре часто (но не всегда) донор информации становится артистом, «исполняющим» свой собственный монолог, обретенный в результате бесед с драматургом, то есть часто перед такой формой театра встает задача безусловного существования артиста, заход театра в нетеатральную зону [6, c. 243].

В образовательной программе Школыстудии МХАТ метод документального театра является одной из ведущих образовательных технологий в постижении актёрского мастерства, его практикуют на каждом курсе.

Заслуженный артист России, профессор Школы-студии МХАТ Д. В. Брусникин одним из первых проявил особый интерес к данному методу и успешно применил его в своей педагогической практике. Первый итог его работы, со студентами актёрского факультета, документальный спектакль «Это тоже я» стал ярким событием в московской театральной жизни, а на Международном фестивале театра и кино о современности «Текстура» был удостоен награды «Приз Зрителя».

Работа над спектаклем строилась следующим образом: студенты, получив творческое задание от педагогов - собрать реальные истории и судьбы людей, отправлялись во всевозможные общественные места, начиная с небольших уличных переулков, заканчивая громадными торговыми центрами, вокзалами и т. п., вели «живой» диалог с незнакомым, чужим человеком, фиксирую это на камеру телефона или диктофон. Далее собранный материал становился поводом для актёрского этюда, где каждый студент «проживал» и воплощал фрагмент, эпизод из жизни теперь уже не чужого человека. Спектакль представлял собой реальную и подробную картину города, которая была собрана из множества историй, услышанных и увиденных молодыми ребятами-студентами, сердца которых полны доброты, безграничной любви и веры в каждого человека.

Рассматривая педагогический потенциал «документального театра» в современной театральной школе, автор статьи обращается к художественному опыту кафедры театральной режиссуры и актёрского мастерства Алтайского государственного института культуры. На кафедре неоднократно осуществлялись постановки, в основе которых лежал метод документального театра. Одной из интересных экспериментальных самостоятельных работ студентов стали этюды на документальной основе, которые представляли собой попытку художественнофилософского осмысления крестьянского 
взгляда на основные причины и последствия депопуляции малых сёл современной России средствами современного театрального искусства. Сбор материала для сценических этюдов производился методами открытого включённого наблюдения, очного полустандартизированного интервью, индивидуальной и групповой свободной беседы, изучения круга документов и материалов по рассматриваемой проблеме (источниковую базу информационно-поисковых работ составили документы и материалы личных, муниципальных, региональных архивов, материалы районной и краевой массовой общественно-политической периодической печати, мемуарная литература, летописи села, календари знаменательных и памятных дат поселений, юбилейные информационные издания и пр.). Информантами стали родившиеся и прожившие жизнь в сельской местности лица пожилого возраста, биографии которых отмечены фактами совершённых в трудных условиях героических поступков, нравственных и трудовых подвигов, выдающихся профессиональных или творческих достижений.

Собранный полевой материал был подвергнут литературно-сценарной обработке и в итоговом варианте представлял собой коллаж сценических зарисовок, этюдов из реальных историй живых людей, невыдуманных монологов и диалогов, элементов устного фольклора, объединённых в стройное повествование рядом сюжетных линий.

Работая над спектаклем, студентам удалось разглядеть и открыть для себя, скрытую за бессобытийностью сельских будней, потрясающую воображение сокровищницу характеров, чудеса бескорыстия, трудолюбия, мужества и долготерпения, головокружительные вершины духа простых людей неприбыльного труда, ухитряющихся, по выражению Виктора Астафьева, до старости сохранить душу «в птенцовом пухе». Студенты посредством художественного осмысления реальной жизни сельского населения пришли к мысли, что критически важным условием духовной безопасности России, стратегической задачей общественного и культурного развития нашего государства является сбережение русского крестьянства.

Музыкально-поэтический спектакль «Ноктюрн» созданный творческими силами студентов и педагогов кафедры театральной режиссуры и актёрского мастерства Алтайского государственного института культуры стал самым удачным опытом использования метода документального театра в образовательной деятель- ности. Спектакль был создан на основе сочинений и рисунков 16-летнего юноши, талантливого художника Никиты Цветкова. Особый интерес к творчеству и жизни Никиты Цветкова в работе над спектаклем для студентов был в том, что о жизненно важных понятиях с ними разговаривал их сверстник - пусть только через свои рисунки, сочинения, размышления. Работа над спектаклем, в процессе которого студенты глубинно погрузились в творчество Никиты Цветкова, поражающее чистотой и глубиной восприятия мира, заставила задуматься о предназначении человека, о смысле жизни, об отношении к вечным ценностям. Наследие, которое оставил после себя 16-летний юноша, вызвало у студентов уважение и восхищение, подарило надежду на будущее, укрепило веру в Россию и любовь к человеку. Студентам удалось передать в спектакле дух подлинного патриотизма, воинской чести и благородства, мужского достоинства, чистой юношеской любви.

Искусствовед Любовь Норгелене в беседа со студентами и педагогами отметила, что в спектакле все гармонично: лаконичность и выразительность обстановки, торжественная строгость костюмов в чёрно-белом цвете, отражающих графику юного художника, тщательный подбор музыкальных произведений, делающих этот спектакль звучащим и ритмичным, а продуманная последовательность произносимых на сцене отрывков из посвящённой Никите Цветкову книги «Я хочу послужить Отчизне» сделала спектакль более уникальным и значимым. Спектакль, в исполнении юных актёров - студентов, проникновенно читающих отрывки из сочинений Никиты, трогал зрителя до слез, заставлял погрузиться в чувства и переживания героев разных эпох.

На основании проведенного анализа можно сделать вывод, что педагогический потенциал документального театра в современной театральной школе невероятно объемен. На сегодняшний день документальный театр является мощным инструментом, который позволяет быстрее других художественных методов находить горячие точки в реальной жизни и создавать вокруг них поле первоначальной рефлексии. Метод документального театра в современной театральной школе помогает студенту понять структуру персонажа, начать абсолютно осознанно разбирать проблему человека, понимать, чем он живёт.

Особым отличием документального театра от современного является то, что современный театр чаще всего является поводом к самовыра- 
жению, а документальный театр действует на художника как «холодный душ», лишая желание к самопрезентации. Документальный театр является методом, ограничивающим свободу художника и в этом своем свойстве представляет чрезвычайно полезный инструмент для образования. Помимо этого, документальный театр является междисциплинарной практикой, которая требует в какой-то степени овладения основами профессии, как журналиста, так и драматурга.

Режиссёр Юрий Квятковский в одном из интервью обозначил возможности документального театра в обучении актёров и режиссёров таким образом: «Они ещё почти дети, но оказывается, что они тоже в состоянии формулировать смыслы. Помимо этого, вербатим помогает вложить в студентов мысль, что театр это гражданский институт, что надо как-то находить себя в этом институте. Наблюдая за какими-то бытовыми, социальными вещами, можно выйти на метафизический уровень» [7].

Таким образом, можно заключить, что документальный театр способствует формированию активной позиции художника, где художник выступает не только в качестве наблюдателя за реальностью, а личностно включается в изучение повседневности. Спектакли, сделанные таким образом, становятся отражением голоса своего поколения с отчетливой гражданской позицией.

\section{Список литературы}

1. Грачёва Л. В. «Есть такая профессия театральный педагог» // Театральная педагогика глазами молодых режиссёров. Санкт-Петербург, 2019. С. 6-12.

2. Товстоногов Г. А. Зеркало сцены. Кн.1: О профессии режиссёра. Ленинград, 1980. $303 \mathrm{c}$.

3. Д. Сибрук. Nowbraw. Москва, 2012. $500 \mathrm{c}$.

4. Богданова П. Культурный цикл: театральная режиссура от шестидесятников к поколению post. Москва, 2017. 479 с.

5. Товстоногов Г. А. Беседы с коллегами: (попытка осмысления режиссерского опыта). Москва, 1988. 527 с.

6. Руднев П. А. Драма памяти. Очерки истории российской драматургии от Розова до наших дней. Москва, 2018. 496 с.

7. Нужно инвестировать в актёрское образование // URL: http://brusfestblog.ru/rudnev-actobrazovanie (25.02.2021).
Н. Н. Головченко, кандидат исторических наук Алтайский государственный педагогический университет (Барнаул, Россия) nikolai.golowchenko@yandex.ru

\section{СЦЕНА БЛИЗНЕЧНОГО КУЛЬТА НА ПЛАСТИНКЕ ИЗ ПОС. КИСЛУХА (ПЕРВОМАЙСКИЙ РАЙОН): СУДЬБА ОДНОЙ НАХОДКИ}

Аннотация. Статья посвящена введению в научный оборот находок (вислообушный топор, два ножа и художественно выполненная нашивная пластинка), выявленных любителем незаконного металлопоиска в поселке Кислуха Первомайского района Алтайского края. Наибольший интерес в данном собрании представляет плоскорельефная пластинка культового литья кулайской археологической культуры, на которой изображены «близнецы». Охарактеризованы одежда и прическа данных персонажей. Предлагается их интерпретация как женщин-сестер или матери с дочерью. Датируется такой образ эпохой раннего железа - раннего средневековья.

Ключевые слова: Верхнее Приобье, эпоха раннего железа, кулайская культура, близнечный культ.

Одним из актуальнейших и животрепещущих вопросов современной охраны объектов историко-культурного наследия является проблема неконтролируемого металлопоиска, приводящего к разрушению объектов археологиче- ского наследия, исчезновению для науки как целостного комплекса, так и его отдельных составляющих путем продажи частным коллекционерам. Введению в научный оборот такой, 